\title{
ジャガイモそうか病の種いも伝染による発生と種いも 伝染に及ぼす土䁃消毒㧍よび種いも消毒の影響
}

\author{
田代 暢哉) ・松尾 良満 (佐賀県畑作試験場)
}

\begin{abstract}
Tuber-borne infection in potato common scab disease and effect of soil sterilization and seed treatment on the control of the tuber-borne infection. Nobuya TASHIRO" and Yoshimitsu MATSUO (Saga Upland Farming Experiment Station, Karatsu, Saga 847-01)

Tests carried out over a period of 5 years indicated the existence of tuber-borne in. fection in common scab of potatoes. When seed tubers in which more than $6 \%$ of the surface area was affected with scab were planted, the scab incidence in the progeny tubers was very high. When seed tubers in which less than $5 \%$ of the surface area was affected with scab were planted the scab incidence was very low and comparable to that when seed tubers devoid of lesions were planted. However in fields disinfected with chlorpicrin, although seed tubers in which $5 \%$ of the surface area was affected and seed tubers without lesions were planted, a severe incidence of the disease was observed. In non-infected fields, the application of copper compounds and streptomycin was effective in controlling scab while in fields which had been disinfected the effect of the application decreased.
\end{abstract}

佐賀県の代表的な畑作地帯である東松浦半島の通称, 上場地域では1973年から土地改良事業が開始され， $5,700 \mathrm{ha} に$ にぶ農地造成・区画整理が現在も続けられて いる。ところが，1977年頃から，この新しく造成された 直後の畑にジャガイモを栽培したところ，そうか病が多 くの畑で一面に発生し，基幹作目として期待されるジャ ガイモの生産振興に大きな打撃を与える結果となった。

ジャガイモそうか病菌の伝染方法には土壇伝染と種! も伝染の 2 通りが知られている。しかし，強酸性で腐植 含量がきわめて少ない土壤「㧍んじゃく」が㕕範囲に 分布している当地域の山林原野を開発した造成畑に本病 原菌が畑地造成以前から存在している可能性は小さいと 考えられる。また，本病原菌は土壤中に局在化する傾向 にある ${ }^{5)}$ とされている。このため造成直後の畑に拀いて 本病が広範囲にわたって発生した原因は土壤伝染よりも 種いも伝染による可能性が高いと考えられた。

そこで, 本病の種いも伝染に関する若干の試験を行っ たのでここに報告する。

\section{試 験 方 法}

各試験とも立武岩細粒赤色土䁃である畑作試験場内主

1）現在 佐賀県果樹試験場
場で実施し、収穫後、40 g 以上の塊荎を次に示す基準で 調查し，発病度を算出した。

発病度 $=\frac{4 \times \mathrm{a}+3 \times \mathrm{b}+2 \times \mathrm{c}+\mathrm{d}}{4 \times \text { 調查塊译数 }} \times 100$

a ：1 塊茎あたりの病斑数が21個以上または病斑面積率 が26\%以上の塊茎数，b：同11〜20個または同13〜25\%， $\mathrm{c}$ ：同 4 10個, d：同 1 3 個

1. 種いも伝染と種いも消毒の効果

1979年から1985年にかけて造成直後のほ場を主体に種 いも消毒試験を行い，あわせて種いも伝染の様相を調査 した。供試薬剤として銅骫（コサイド水和剤）またはス トレプトマイシン剂（アグリマイシン100）を用い，銅 剤では100倍液・30分間浸漬処理，ストレプトマイシン 剤では100倍液・瞬間浸漬処理とした。1979，80，82年 の試験では病斑面皘率26～50\%の䍜病塊茥を，1984，85 年の試験では塊茥あたりの病斑数が 2 4 個の䍜病塊茎 を用いた。試験区の面積は年次によって異なるが3.6〜 $7.2 \mathrm{~m}^{2}$ で 3 連制とした。

2. 種いも伝染に及ぼす種いもの罹病程度の影響

第 2 表に示すような病斑面積率の異なる罹病塊茎と無 病斑塊茎（激発、少発および無発病の各ほ場加無病斑 のものを採取）を植付け，種いもの䍜病程度の違いが発 
病に及ほす影響について検討した。供試ほ場は開畑後 2 か年経過したジャガイモ未栽培ほ場（土壤 $\mathrm{pH} ： 6.0$ ）で, 試験の規模は 1 区 $3.6 \mathrm{~m}^{2}, 3$ 連制とし，地表下 $30 \mathrm{~cm}$ の深 さまで波板を埋込み，区の境界を区切った。植付は1982 年 9 月 5 日で12月20日に収穫した。

3. 種いも伝染に及ぼす土壤消毒および種いも消毒の

\section{影響}

造成直後の作物未栽培ほ場では土䁃微生物フロラがき わめて蟹弱で, 病原菌の侵害に対する緩衝能力が小さい こと离が明らかとなっている。そこでこのモデルとして クロルピクリン消毒を行い土壤微生物フロラを単純化し たほ場で本病の種いも伝染について検討した。すなわち， 第 3 表に示すように土壌消毒の有無抢よび種いも消毒の 有無を緗合せ，これらの処理が種いも伝染に及ばす影響 を調へたた。試験は造成後, 飼料作物を 3.5 年間栽培し たほ場（土銥pH：6.0）で行った。土壤消毒にはクロル

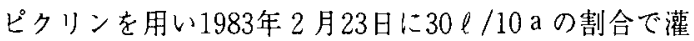
注後直ちに古ビニールで被覆し，4週間後および 5 週間 後の 2 回ガス抜きを行った。供試種いもは病斑面積率 $50 \%$ 抢よび $5 \%$ の䍜病塊荎と少発ほ場（発病塊茎率 18\%) から採取した無病斑塊茎である。種いも消毒は 3 月29日に銅剂（コサイド水和剂）100倍液に瞬間浸漬す ることによって行い，風乾後，塊茥単位方式で切断した。 試験の規模は 1 区 $3.6 \mathrm{~m}^{2} ， 3$ 連制とし，地表下 $30 \mathrm{~cm}$ の深 さまで波板を埋迟み、区の境界を区切った。植付は 4 月 2 日で 7 月20日に收穫した。
結

果

1. 種いも伝染と種いも消毒の効果

第 1 表に示すように年次および作期によって差はある ものの, 䍜病種いもを植付けた場合, 新塊茥に本病が発 生することから本病の種いも伝染は明らかであった。銅 剂およびストレプトマイシン剂による種いも消毒の効果 は春作では高く，実用上問題とならない程度にまで新塊 茎の発病を防止した。しかし，多発生の傾向にある秋作 ではやや少る傾向にあった。なお，対照として用いた無 病斑種いも，すなわち見かけ上は健全な種いもを植付け た場合にも発病が認められ，1979年秋作，84年春作䇽よ び85年春作のように䍜病種いもを薬剂処理した場合より も発病が激しい場合もみられた。

2、種いも伝染に及ぼす種いもの䍜病程度の影響

種いもの罹病程度の違いが新塊荎の発病に及ぼ影響 をみたのが第 2 表である。病斑面積率が $6 \%$ 以上の罹病 種いもを植付けた場合，病玟面皘率の多少にかかわらず 新塊茥に招ける発病塊茥率70\%以上，発病度 35 以上と多 発した。これに対して病斑面積率 5〜1\%の䍜病種いも の場合には発病塊茎率 $25 \%$ ，発病度 8 であり，無発病は 場から採取した無游斑種いもと同程度の発生であった。 また，前作における発生状況が異なるほ場から採取した 無病斑種いもを植付けた場合，すべて同程度の発生状況 で，前作における発生の多少が種いも伝染に及ぼす影響 は明らかでなかった。

3. 種いも伝染に及ぼす土壤消毒および種いも消毒の

第 1 表 ジャガイモそうか病の種いも伝染と種いも消毒の効果

\begin{tabular}{|c|c|c|c|c|c|c|}
\hline 次 & 作 期 & 供 試 薬 剂 & $\begin{array}{l}\text { 希釈倍数 } \\
\text { 浸港時間 }\end{array}$ & $\begin{array}{l}\text { 登病塊萻 } \\
\text { 率 }\end{array}$ & 発满度 & 供試ほ場の状況 \\
\hline \multirow{3}{*}{1979} & \multirow{3}{*}{ 秋 作 } & 銅＼cjkstart剮 & \multirow[t]{3}{*}{100 倍· 30 分 } & 39 & 11 & \multirow{3}{*}{$\begin{array}{l}\text { 造成後 } 1 \text { 作目 } \\
\mathrm{pH} 6.5\end{array}$} \\
\hline & & 無処理（罹病いも）」 & & 89 & 37 & \\
\hline & & 無処理（無病斑いも） & & 65 & 22 & \\
\hline \multirow{3}{*}{1980} & \multirow{3}{*}{ 春 作 } & 銅＼cjkstart剂 & \multirow[t]{3}{*}{100 倍· 30 分 } & 5 & 1 & \multirow{3}{*}{ 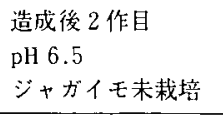 } \\
\hline & & 無処理（慛病いも）a & & 39 & 11 & \\
\hline & & 無处理（無病斑いも） & & 5 & 1 & \\
\hline \multirow{3}{*}{1982} & \multirow{3}{*}{ 秋 } & 釦＼cjkstart都 & \multirow[t]{3}{*}{ 100倍・瞬間 } & 59 & 25 & \multirow{3}{*}{ 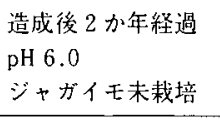 } \\
\hline & & 無処理 (罹病いも) & & 82 & 41 & \\
\hline & & 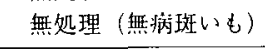 & & 23 & 8 & \\
\hline \multirow{3}{*}{1984} & \multirow{3}{*}{ 春 } & ストレプトマイシン剂 & \multirow[t]{3}{*}{ 100倍・瞬間 } & 11 & 3 & \multirow{3}{*}{ 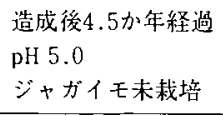 } \\
\hline & & 無処理 (罹病いも) & & 46 & 21 & \\
\hline & & 無処理（無病斑いも） & & 24 & 9 & \\
\hline \multirow{3}{*}{1985} & \multirow{3}{*}{ 春 } & ストレプトマイシン剤 & \multirow[t]{3}{*}{ 100倍·瞬問 } & 2 & 1 & \multirow{3}{*}{$\begin{array}{l}\text { クロルピクリン消毒 } \\
(30 \ell / 10 \mathrm{a}) \\
\text { pH } 5.0\end{array}$} \\
\hline & & 無処理 (罹病いも) ${ }^{\circ}$ & & 34 & 16 & \\
\hline & & 無処理（無病斑いも） & & 18 & 8 & \\
\hline
\end{tabular}

a : 病斑面積率 $26 \sim 50 \%$

b：1塊荎あたりの病斑数が $2 \sim 4$ 個 


\section{影響}

種いも伝染に及ぼす土塨消毒および種いも消毒の影響 をみたのが第 3 表である。無消毒ほ場に病斑面皘率50\% の痽病種いもを植付けた場合，発病塊茎率 $52 \%$, 発病度 21 と多発生したが，病斑面積率 $5 \%$ 拉よび無病斑の種い もの場合には少発生で前述の試験結果と一致していた。 さらにこれらの種いもを消毒した場合，発病は著しく減 少し，高い種いも消毒効果が得られた。これに対して， クロルピクリン処理ほ場では種いもの病斑の有無および 病斑面積率の多少にかかわらず多発生した。すなわち， 無病斑種いもを植付忛た場合でも発病塊茎率 $82 \%$ ，発病 度49と無消毒ほ場の無病斑種いもの場合に比べ，きわめ

第2裴 ジャガイモそう称病の種いも伝染に及ばす 種いもの罪病程度の影輩。

\begin{tabular}{|c|c|c|c|c|}
\hline & $\begin{array}{l}\text { 種いもの病斑 } \\
\text { 面積率 }(\%)\end{array}$ & $\begin{array}{l}\text { 発病塊莘渠 } \\
(\%)\end{array}$ & 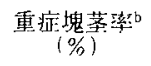 & 発病度 \\
\hline & $100-76$ & 88 & 47 & 39 \\
\hline & $75-51$ & 75 & 48 & 35 \\
\hline & $50-26$ & 82 & 56 & 41 \\
\hline & $25 \sim 6$ & 70 & 48 & 35 \\
\hline & $5 \sim 1$ & 25 & 7 & 8 \\
\hline & 無病斑 Ic & 23 & 7 & 8 \\
\hline & 無怗斑 II ${ }^{\mathrm{d}}$ & 28 & 5 & 8 \\
\hline & 無病斑 [II & 29 & 5 & 8 \\
\hline \multicolumn{5}{|c|}{ 供試ほ場の土壤 $\mathrm{pH}: 6.0$} \\
\hline $\mathrm{b}$ & \multicolumn{4}{|c|}{1 塊菨あたりの病斑数が 4 個以上の塊萻の割合 } \\
\hline c & \multicolumn{4}{|c|}{$\begin{array}{l}\text { 前作の激発ほ場 (発病塊蕫率 } 98 \% \text { ) 功採取した無病玟 } \\
\text { 種いも) }\end{array}$} \\
\hline \multicolumn{5}{|c|}{ d "小発ほ場（発病塊茥率12\%) } \\
\hline e & \multicolumn{4}{|c|}{ "典発病は場 } \\
\hline
\end{tabular}

て発生が多くその程度も高かった。また，種いも消毒を 行っても，その発病抑制効果は與消毒ほ場に比べ著しく 少っていた。

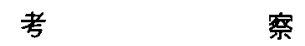

ジャガイモそうか将の種いも伝染についてはこれまで いろいろの評価がなされてきたが，一般に否定的な報告 1.2.5.71 が多い。これに対し，本試験では将斑面積率 $6 \%$ 以上の型病種いもを植付けた場合，種いも伝染に上る新 塊荎の発病は高率に安定して起って拐り，本病の伝染方 法としての種いも伝染の重要性が確認された。しかし, 実際には無病斑，すなわち見かけ上健全な種いもやわず かの病斑を有する種いもが植付けられた場合に，どの程 度種いも伝染による本病の発生が起こるのかということ が重要な問題である。

造成直後の畑やクロルピクリン処理畑という特殊な条 件下に見かけ上健全な無病斑種いもを植付けた場合，㷳 病種いもを消毒したときよりも多発することがあり，伝 染源として無病斑種いもの重要性が示唆された。事実, クロルピクリンによる土壊消毒を行ったほ場では，無消 毒は場では多発生につながらない病斑面積率 $5 \%$ の慛病 種いもや無病斑種いもを植付けた場合でも多発し，種い も消毒の效果も著しく劣っていた。このことから土畩消 毒によって土壤微生物フロラが単純化された土壤では見 かけ上健全な無病斑種いもであっても伝染源となり得る ことが明らかとなった。さらに谷井 ${ }^{11}$ も指摘している ように一般土壤微生物による本病の発病抑制効果の高い

第 3 表 ジャガイモそうか病の種いも伝染に及はす土壤消毒㧍よび種いも消毒の影響

\begin{tabular}{|c|c|c|c|c|c|c|c|c|c|}
\hline \multirow{2}{*}{ 土壤消毒 } & \multirow{2}{*}{ 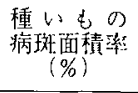 } & \multirow{2}{*}{ 種いも消㴗b } & \multicolumn{5}{|c|}{ 発病程度別塊䔄割合 $(\%)$} & \multirow{2}{*}{$\begin{array}{c}\text { 発病塊萻率 } \\
(\%)\end{array}$} & \multirow{2}{*}{ 発病度 } \\
\hline & & & 0 & 1 & 2 & 3 & 4 & & \\
\hline \multirow{6}{*}{ 無 } & \multirow[t]{2}{*}{50} & 有 & 93 & 4 & 2 & 0 & 1 & 7 & 3 \\
\hline & & 無 & 48 & 27 & 20 & 3 & 2 & 52 & 21 \\
\hline & \multirow[t]{2}{*}{5} & 有 & 99 & 1 & 0 & 0 & 0 & . 1 & 1 \\
\hline & & 無 & 83 & 10 & 5 & 1 & 1 & 17 & 7 \\
\hline & \multirow[t]{2}{*}{0} & 有 & 95 & 4 & 1 & 0 & 0 & 5 & 2 \\
\hline & & 摽 & 89 & 7 & 4 & 0 & 0 & 11 & 4 \\
\hline \multirow{6}{*}{$\begin{array}{l}\text { タロルピクリン } \\
30 \ell / 10 \mathrm{a}\end{array}$} & \multirow[t]{2}{*}{50} & 有 & 5 & 8 & 30 & 19 & 38 & 95 & 69 \\
\hline & & 無 & 1 & 7 & 19 & 23 & 50 & 99 & 79 \\
\hline & \multirow[t]{2}{*}{5} & 有 & 58 & 16 & 20 & 4 & 2 & 42 & 19 \\
\hline & & 無 & 6 & 12 & 30 & 27 & 25 & 94 & 63 \\
\hline & \multirow[t]{2}{*}{0} & 有 & 70 & 15 & 12 & 0 & 3 & 30 & 13 \\
\hline & & 無 & 19 & 21 & 27 & 14 & 19 & 81 & 49 \\
\hline
\end{tabular}

供試ほ場の土㙞 $\mathrm{pH}: 6.0$

銅剂100倍液・瞬間浸清処理

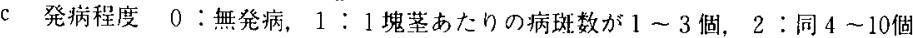

3 : 同11～20個または将斑面積率 13 ～25\%

4 ：同21個以上または同 $26 \%$ 以上. 
ことも示唆された。また本病は土壤 $\mathrm{pH} ゙$ 弱酸性〜中性 域でその発生が多い6)ことが知られている。このため土 懔微生物フロラがきかめて負弱で，アルカリ資材によっ て土壤pHが 6.5 程度に矯正された当地域の造成直後の畑 "は種いも伝染による本病の発生がきわめて起こりやす い条件にあるものと考えられる。

篠田ら ${ }^{91}$ は開墾地ほ場では開笮後少なくとも数年間は 特に土壤病害対策に留意することが必要であると述べて いる。当地域の造成畑においても同様のことがあてはま ると考えられ，本病原菌の侵入を防ぐため無病種いもの 選別や種いも消毒の徹底を図る必要がある。さらに，造 成畑では造成直後からジャガイモを栽培するのではなく 他作物を数回作付して土壇微生物フロラが豊かとなり熟 畑化過程において病害に対する緩衝能力が強まった後に ジャガイモの栽培を行うことが望ましいと考えられる。

なお，本病の病原菌として遺伝的類縁関係の異なる数 種のStreptomyces 属放線菌の存在が明らかとなってい
己10)。今後は，それぞれの Streptomyces 属放線菌につい てその種いも伝染の様相を明らかにしていくことも必要 であろう。

\section{引用 文 献}

1) Adars, M. J. and Hide, G. A. (1981) Ann. appl. Biol 98 211-216. 2) Cairns, H., Greeves, T. N. and Muskett, A. E. (1936) Ann appl. Biol. $23: 718-742.3$ 3) 池田一徹 -小柳芳 即・本原唯幸・田中茂雄 (1974) 九農研36:167。4）九州 農政局（1985）営農技術確立調査（新盉烟土壤熟化調查）湊地 区報告書。 5) LAPWOOD, D. H. (1972) PI. Path 21 : 105-108 6) 水澤芳次郎 (1935) 農及園 10:1341-1350. 7) SCHAAL, L. A. (1946) Am. Potato J. 23 ：163-170. 8) 篠田辰彦.太田 侓・飯田 格 (1966) 東北農試研究報告 $33: 425-573 ， 9$ ) 篗田辰彦・太田 庸·飯田 格·君々袋尚志 (1979) 日植病報 45：478-483，10）田代暢哉·宮下清貝・鈴井孝仁・松尾良渵 （1986）日植将報 61 (印刷中). 11) 谷井昭头 (1985) 放線 藏の分類と特性研究会資料（農業環境技術研究所編）：31-52.

(1986年6月17日 受領) 